\title{
Implementation of Ta'widh (Compensation) for Default Customers at KPR Platinum iB in the Perspective of Fatwa DSN-MUI No.129 / DSN-MUI / VII / 2019 at Bank BTN KCPS Karawaci
}

\author{
Abdul Rachman', Fikriana Aini' \\ 1,2Sekolah Tinggi Ekonomi Syariah (STES) Islamic Village, Indonesia \\ abdul@stes.isvill.ac.id
}

\begin{abstract}
Purpose - This study aims to determine the implementation of ta'widh (compensation) for defaultcustomers on KPRPlatinum iBin the perspective of Fatwa DSN-MUI No.129 / DSN-MUI / VII / 2019.
\end{abstract}

Method - This study uses a qualitative analysis method with data collection techniques through observation, in-depth interviews and documentation. Purposive sampling technique is used by selecting sources who are considered the most knowledgeable related to the research topic.

Result-The results of this study indicate that the implementation of ta'widh for defaultcustomers on the KPR Platinum iB is in accordance with the DSNMUI Fatwa No.129 / DSN-MUI / VII / 2019. But in practice, there are several notes. The implementation of ta'widh and ta'zir at BankBTN KCPSKarawaci is different. Ta'widh is charged to customers who experience delays in paying their obligations for more than 180 days and the ta'widh funds obtained will be recorded as Bank revenue. Ta'zir will be charged to customers who do not pay installments according to the due date and the ta'zir funds obtained will be recorded as non-halal income.

Implication - This research can be used as a reference in measuring the conformity between the DNS-MUI Fatwa No. 129 / DSN-MUI / VII / 2019 with its implementation in the practice of financing in Islamic banks.

Originality - This research focuses on analyzingimplementation of ta'widh (compensation) for defaultcustomers on KPRPlatinumiBin theperspective of Fatwa DSN-MUI No.129 / DSN-MUI / VII / 2019.

Keywords: Ta'widh, Default, Sharia KPR, Fatwa DSN-MUI.

AL-ARBAH: Journal of Islamic Finance and Banking - Vol. 2 No. 2 (2020) 
Abdul Rachman, Fikriana Aini

\section{Introduction}

Bank BTN Syariah is a Sharia Business Unit (UUS) of Bank BTN which carries out its business activities based on sharia principles. The superior financing product in Bank BTN Syariah is the KPR (Home Ownership Credit) product. There are three types of KPR products available in Bank BTN Syariah, namely KPR Sejahtera iB, KPR Platinum iB and KPR Indent iB. The superior financing product in Bank BTN Syariah is the KPR (Home Ownership Credit) product. Sharia KPR financing at Bank BTN KCPS Karawaci continues to increase every year. The mortgage growth table is as follows:

Table 1. Home Ownership Credit Financing Growth

\begin{tabular}{cccc}
\hline \multicolumn{1}{c}{ Information } & 2017 year & 2018 year & 2019 year \\
\hline Total Financing & Rp. 50,049,859,115 & Rp. 87,725,520,063 & Rp. 150,700,040,667 \\
\hline Number of Customers & 79 & 131 & 201 \\
\hline
\end{tabular}

Source: KPR Financing Facility Recapitulation Document

The increase in the amount of mortgage financing every year is not in line with the number of collectability customers which also has increased every year, namely as follows:

Table 2. Total Customer Collectibility

\begin{tabular}{lccc}
\hline \multicolumn{1}{c}{ Collectibility } & $\mathbf{2 0 1 7}$ year & $\mathbf{2 0 1 8}$ year & $\mathbf{2 0 1 9}$ year \\
\hline Coll 1 (Current) & 67 & 114 & 184 \\
\hline Coll 2 (Special Mention) & 10 & 14 & 14 \\
\hline Coll 3 (Sub Standard) & 0 & 1 & 1 \\
\hline Coll 4 (Doubtful) & 0 & 0 & 0 \\
\hline Coll 5 (Traffic) & 2 & 2 & 2
\end{tabular}

Source: Document of Collectibility of KPR Bank BTN KCPS Karawaci Financing Facility Recapitulation

The table above shows that customers classified as coll1 (current) have increased every year. Coll 2 customers (under special mention) from 2017 to 2018 increased by four customers and the number of customers remained stable until 2019. In addition, the number of coll 3 (substandard) customers also increased from previously no customers to one customer and the number of customers has also remained stable until 2019. 
The risk that must occur when the bank distributes financing is default or default. Non-performing financing is financing that according to its quality is based on the possible risk of the condition and compliance of the financing customer in fulfilling the obligation to pay for the results, as well as paying off the financing (Nihayah \& Rifqi, 2020) If the customer is proven to have defaulted, that is deliberately not carrying out his obligations in accordance with the agreement that has been made (Pangestu, 2019) so that the bank experiences a loss, the bank is allowed to impose sanctions on the customer (Faqihuddin \& Yazid, 2017).

Losses experienced by banks due to default customers, namely the bank will incur additional costs. These costs are in the form of costs incurred for making notification letters to customers, telephone fees and other costs incurred by the bank due to customer negligence in making payments. In addition, delayed payments made by customers can affect bank capital. Banks cannot use these funds for other businesses.

The losses experienced by the bank due to customer default are not in line with Islamic sharia principles which prioritize the interests of the parties conducting transactions, both the bank and the customer, so that the rights and interests of the transacting party are not harmed by the application of ta'widh (compensation) and ta ' zir (fines) is a form of protection in sharia financial institutions that is made in accordance with sharia principles to cover losses experienced by banks.

Based on the description above, researchers are interested in conducting more in-depth research on how to apply ta'widh (compensation) to default customers, so the author takes the research title "Implementation of Ta'widh (Compensation) for Default Customers on KPR Platinum iB in Perspective Fatwa DSN-MUI No.129 / DSN-MUI / VII / 2019 at Bank BTN KCPS Karawaci." 
Abdul Rachman, Fikriana Aini

\section{Literature Review}

\section{Implementation}

In simple terms implementation means application or implementation. There are three factors that must be present in the implementation process according to Gratitude in Surmayadi (2005), namely as follows: (1) there is a policy being implemented (2) the target of policy implementation and the beneficiaries of the policy (3) the implementing element (implementor) that will be be responsible and supervise as long as the policy is implemented (Heriadi, 2017).

\section{Ta'widh}

Ta'widh has a word origin, namely عَاضنَ- يَوُوْضُ عَوْضنًا - عِوَضًا which means to replace or (Yunus, 1989). Ta'widh literally means to replace or pay compensation. Whereas in terms of covering losses that occur as a result of violations committed (Gozaly, 2019). In the world of Islamic Banking, ta'widh is a form of compensation charged to customers who experience delays in paying their obligations. The cost of compensation that must be paid by the customer is in the form of costs that have been incurred by the Bank when the customer experiences default or default (Sholihin, 2013).

Losses charged to customers are real losses experienced by the Bank where the amount of the loss must be calculated in detail and is not a loss that has been predicted and calculated from the start (potential risk) that the loss will occur at a later date due to opportunities lost, opportunity loss (Faqihuddin \& Yazid, 2017).

Basically ta'widh and ta'zir are two different things. Ta'zir is the mashdar form of the word عزارة ('azzarah) which means to reject and prevent. According to the terms of the Shari'a, ta'zir is a punishment for mistakes that have no had law, nor kifarat in it. Ta'zir in the banking world is defined as a form of sanction given by Islamic banks to customers who are able to pay their obligations on purpose or for other reasons that are not justified in syar'i and there is no desire and good faith to pay their obligations on time (Nani, 2018). The 
Implementation of Ta'widh (Compensation) ...

sanctions given are in the form of fines, the amount of which is predetermined and stated in the contract agreement.

\section{Default}

Default comes from the Dutch language which means bad performance, where someone is negligent or does not fulfill their obligations in accordance with the predetermined agreement between the creditor and the debtor (Suadi, 2018). According to Subekti, a person can be said to be in default if (Yahman, 2016):

1. Not doing something that was promised to be done.

2. Doing something that was promised, but not as promised.

3. Doing something that was promised, but too late.

4. Doing something that is according to the agreement should not be done.

In general, default will occur when someone has been declared negligent because they do not fulfill the obligations contained in the agreement. In other words, default will occur if the party who breaks the promise cannot prove that the act of breaking the promise occurred because of coercive circumstances inbeyond its power (force majeure). If the time limit is not determined in the fulfillment of the agreement, the creditor is obliged to give a warning to the debtor so that he can carry out his obligations (Simanjutak, 2017).

\section{KPR (Home Ownership Credit)}

KPR is a credit product provided by banks for customers who want to own a house but cannot afford to buy a house in cash (Kuswati, 2015). KPR Syariah is a home ownership financing product provided by Sharia Financial Institutions such as Sharia Banks based on Sharia principles with the aim of helping people own houses and land.

KPR financing contained in Sharia Banks uses two types of contracts, namely murabahahand istishna. Murabahah contract, namely a sale and purchase agreement with an additional margin (profit) as an advantage for 
Abdul Rachman, Fikriana Aini

Islamic Banks. Murabahah contract is a sale with an agreed profit margin (Mashilal, 2020). An istishna contract is a sale and purchase contract that is carried out through an order for goods with certain specifications between the buyer and recipient of the order and payment is made in accordance with the agreement of the two parties whether the payment is made in advance, in installments or in installments or is postponed until the agreed time (Usman, 2010).

\section{Fatwa DSN-MUI No.129 / DSN-MUI / VII / 2019}

General provisions consist of (1) ta'widh (compensation) is an amount of money or goods that can be valued with money that is charged to a person or entity for defaulting; (2) real costs are direct costs incurred as a result of default; (3) Default or breach of promise is doing something that should not be done (al-ta'addi), not doing what should be done (al-taqshir), or violating what has been agreed (mukhalafat al-syuruth).

Real Cost Provisions consist of (1) bthe real cost that can be imposed by LKS on customers can be traced (traceability) on billing costs and real losses that have actually occurred, directly related to collection costs and losses due to variable cancellations that have occurred (incurred direct variable costs) and the amount or value must meet the principles of propriety, reasonableness, and normality (Arm's Length Principle / AlP); (2) bthe real cost in the context of collecting the result of default can be in the form of real fees for the use of third party services for collection; (3) breal costs in the context of collection due to default can be in the form of real fees without the use of third party services for collection, including, among others, costs for communication, correspondence, travel, legal consulting services, notarial services, taxation; and overtime and extra work.

The provisions of Ta'widh consist of (1) Ta'widh may only be charged to customers for real costs incurred due to default; (2) The amount of this compensation fee cannot be stated in the contract, and cannot be stated in the form of a formula; (3) Ta'widh funds received by LKS can be recognized as compensation for real costs that have been incurred (replacement cost); and 
Implementation of Ta'widh (Compensation) ...

may not take the excess of the compensation (ta'widh) that was charged; (4) Real costs must be assessed at nominal.

Closing Provisions, namely pen Dispute resolution must be carried out in accordance with Sharia principles and applicable laws and regulations, namely through deliberation to reach consensus or through dispute resolution institutions, namely the National Sharia Arbitration Board (BASYARNAS) and the Religious Courts.

\section{Methods}

This research method is qualitative research with the type of study case research. Qualitative research is a descriptive type of research in which the findings do not use numbers related to statistics, but through data collection, data analysis and interpretation (Anggito \& Setiawan, 2018). The type of research in this research is a case study because research is carried out based on real events or events that are happening in life, whether related to individuals or groups or institutions within a certain period of time (Nurdin \& Hartati, 2019).

Data collection techniques used consisted of observation, interviews conducted with Branch Manager Bank BTN KCPS Karawaci, Financing Service Bank BTN KCPS Karawaci, Platinum iB KPR Financing Customers and Experts / Experts Ta'widh. The documentation used is in the form of KPR agreement documents, documents for determining the limit value of the auction plan, a document recapitulation of the collectability of KPR financing facilities and documentary evidence in the form of photographs of research results.

The data validity test used in this study consisted of

Test Credibility, The data credibility or trust test is used to ensure the data that has been obtained is valid or not.

Test Transferability, In test transferability, researchers are required to describe the results of their research by describing in detail, clearly, structured and reliable the results of their research. So that readers can understand the results of the research. 
Abdul Rachman, Fikriana Aini

Test dependability also called reliability, which is done by auditing the entire research process. A study can be trusted if the research results can be repeated by other people.

Test confirmability aims to test the results of research through the research process carried out. If the research results have been approved by many people, the research can be declared objective.

\section{Results and Discussion}

\section{Implementation of Ta'widh at Bank BTN KCPS Karawaci in the Perspective of the DSN-MUI Fatwa No.129 / DSN-MUI / VII / 2019}

Default customers are often found in iB Platinum KPR financing products because the amount of the financing installments for this product is higher when compared to the iB Subsidized KPR product. Customers have started to be said to be in default when they do not make installment payments according to a predetermined due date (Sarjadinata, 2020) and customers do not fulfill their obligations properly or violate the terms of the contract that have been agreed since the beginning (Kukuh, 2020).

The factors that cause customers to default are due to two things (Hariyanti, 2013). First, there is bad faith carried out by the customer or in other words, the customer commits negligence such as forgetting to pay installments every month (Hermawan, 2020) and the date of income that is far from the due date of the financing (Endang, 2020). Second, there is a situation that forces (overmacht or force advanced) beyond the ability and willingness of the customer, such as economic difficulties that are being felt by the customer either because the business run by the customer goes bankrupt or due to elements of layoffs (termination of employment), especially at this time due to the effect Covid-19 virus pandemic (Kukuh, 2020).

There are several things that banks do when a customer defaults, namely as follows (Sarjadinata, 2020):

SMS Blush, before the due date of payment the bank will send SMS Blush to the customer to remind that the installment payment will be due; Contact 
Implementation of Ta'widh (Compensation) ...

customers by telephone; Provide a warning letter; Provide warning letters starting from SP 1 to SP 3; Carry out the execution of the collateral auction.

The bank can determine the cost of compensation to the customer when the Bank has made a subpoena to the customer. This warrant is in the form of a warning letter or warning letter issued by the Bank to customers who commit default with the aimto remind customers to fulfill their obligations in accordance with the agreement. In general, summons are carried out three times, namely first level summons, second level summons and third level summons (last).

When the customer is included in the category coll 4 and 5 banks will carry out the execution of the house or collateral auction. To do this requires a long and long process so that the Bank has to pay a large amount of costs. These costs are in the form of feesappraisal, advertising costs, SKPT (Land Registration Certificate) fees, BLS (Private Auction Hall) fees of 3\% of the auction price, income tax fees of 2.5\%, administration fees of the KPKNL (State Wealth and Auction Service Office) of $2,5 \%$. This cost is called the real cost inta'widh (compensation). These costs will be recorded in detail by the Bank (Bank BTN KCS Tangerang, 2020).

The bank will auction off Mr. Rendy's collateral in Depok with a land area of 75/60 m2. The remaining principal amount of financing that Mr. Rahman did not pay was Rp. 181,153,574. The total estimated cost to be incurred by the Bank when conducting collateral auction is Rp.18,342,143. From the results of the appraisal conducted by the Bank, the selling price of the collateral if adjusted to the market price is Rp. 240,750,000. However, if adjusted for the liquidation price, the collateral price is much lower, namely Rp. 180,562,500. So that the Bank will set the collateral price of Rp. 200,000,000 up for auction.

In practice, these costs will not be charged to customers because these costs are already included in the price of the house to be auctioned by the Bank. If it turns out that the house is sold at a price that is in accordance with the remaining principal of customer financing, the auction fee that has been incurred by the Bank will not be borne by the customer, but these costs will 
Abdul Rachman, Fikriana Aini

still be borne by the Bank. Branch Offices will request principle permits from the Head Office so that the auction fees that have been issued by the bank can be included in the rescue budget (Sarjadinata, 2020). The results of the auction or home sale are prioritized to pay off all the remaining principal of customer financing including all costs incurred by the Bank when conducting the auction. If there is any residual from the house sale made by the Bank,KPR Platinum iB Agreement Documents).

Fund ta'widh obtained by Bank BTN KCPS Karawaci will be recorded as Bank income as a form of compensation for the real costs that have been incurred by the Bank when carrying out the auction execution. But different fromta'zir (fines), the cost of fines (ta'zir) will be recognized or recorded as non-halal income or included in funds qardhul hasan or currently known as CSR funds (Corporate Social Responsibility). The funds will be collected to be used for the Bank's social activities (Sarjadinata, 2020).

The amount of compensation costs ( $t a^{\prime}$ widh) not included in the contract agreement because the cost of compensation (ta'widh) for each customer is not the same (Sarjadinata, 2020). If the bank has included this fee in the agreement, it is the same as usury because something that is not certain to happen has been determined from the start (Herijanto, 2020). However, the fee for the fine (ta'zir) that has been stated in the contract agreement is Rp. 67 $x$ Number of Days in Arrears (Kukuh, 2020).

If there is a dispute in the implementation of the provisions of the agreement, the Bank will take the first step, namely to resolve it by deliberation. If by deliberation the dispute cannot be resolved, it will be resolved through the Religious Court in the jurisdiction where the Bank's Sharia Branch Office (KPR Platinum iB Agreement Documents).

Based on the description above, it can be concluded that the implementation of ta'widh (compensation) for non-performing customers at Bank BTN KCPS Karawaci is in accordance with Fatwa No. 129 / DSN-MUI / VII / 2019 concerning Real Costs as Ta'widh for Default Customers. However, 
Implementation of Ta'widh (Compensation) ...

there are few records in the practice of implementing ta'widh carried out by Bank BTN KCPS Karawaci.

\section{Difference between Ta'widh (Compensation) and Ta'zir (Fines) at Bank BTN KCPS Karawaci}

$T a^{\prime} z i r$ is a sanction in the form of payment of an amount of money imposed on a customer who is able to pay but delays the obligation to pay installments with an element of intent. The bank will determine ta'zir to customers who experience delays in paying installments for one day or when the customer does not pay its obligations on the due date. The ta'zir fee has been recorded in the contract agreement so that the customer is aware of the amount of fine that will be charged when experiencing delays in paying installments, namely every multiple of the arrears of Rp. 100,000, - will be subject to a fine (ta'zir) of Rp. 67 $\mathrm{x}$ Number of Days in Arrears. The calculation of ta'zir fees set by the bank for customers is as follows:

Mr. Rio bought a house for Rp. 146,672,700, - through KPR Platinum iB financing at Bank BTN KCPS Karaawaci with a financing period of 60 months (5 years). Every 20th Mr. Rio must pay an installment of Rp. 2,444,545, -. Mr. Rio did not make an installment payment on the 20th because he received income every 28th. So that the fine (ta'zir) set by the bank to Mr. Rio was:

Monthly Installments: Rp. 2,444,545, -

Ta'zir (fine) : : Every multiple of the arrears of Rp. 100.000, - will be charged ta'zir (fine) Rp. 67 x Number of Days in Arrears

Multiples of Rp. 100,000, - from Rp. 2,444,545, - is 24

Thus, 24 x Rp. 67, - 8 (days) = Rp. 12,864, -

Then the fine set by the Bank to Mr. Rio is Rp. 12,864, -

The cost of the fine (ta'zir) will be recognized or recorded as non-halal income or included in funds qardhul hasan or currently known as CSR funds (Corporate Social Responsibility). The funds will be collected to be used for the Bank's social activities. 
Abdul Rachman, Fikriana Aini

\section{Conclusion}

The results of this study indicate that The implementation of ta'widh (compensation) for default customers on KPR Platinum iB is in accordance with the DSN-MUI Fatwa No.129 / DSN-MUI / VII / 2019 concerning Real Costs as Ta'widh for Default. However, there are some notes on the practice of implementing ta'widh by Bank BTN KCPS Karawaci. The first note in the general provisions of the first point is that the ta'widh fee is not charged to the customer because the cost is included in the price of the collateral or the house to be auctioned. The second note is in the provisions of the real cost, the first point is that the real costs charged by the bank to the customer are real costs that have been incurred by the bank when executing collateral auction, not based on the billing fees that have been made by the bank.

The third note is in the provisions of the second point real cost, namely Bank BTN KCPS Karawaci using third party services, namely Private Auction Hall (BLS) services when the bank has executed collateral or house auction executions and this fee is included in the real cost category that must be paid by the customer. The fourth note is contained in the real cost provisions, the third point is communication costs, travel costs and overtime and extra work costs are not included in the real cost category.

Based on the results of the research and discussion above, the suggestion that the author can convey is that Banks must be careful in providing financing to customers, especially in financing KPR Platinum iB by prioritizing the prudential principle which refers to the $5 \mathrm{C}$ analysis (Charcter, Chapacity, Capital, Condition, Collateral). This must be done by the Bank to minimize the risk of problematic financing such as bad financing due to customers not paying their obligations and to minimize losses arising from problematic financing. 
Implementation of Ta'widh (Compensation) ...

\section{References}

Anggito, A., \& Setiawan, J. (2018). Metodologi Penelitian Kualitatif. Sukabumi: CV. Jejak (Jejak Publisher).

Dokumen Penentuan Nilai Limit Rencana Lelang Bank BTN KCS Tangerang, 2020

Endang. Wawanancara dengan nasabah KPR Platinum iB Bank BTN KCPS Karawaci. , (2020).

Faqihuddin, A., \& Yazid, M. (2017). Implementasi Kebijakan Fatwa DSNMUI No. 43/DSN-MUI/VIII/2004 Tentang Ta'widh Bagi Nasabah Wanprestasi. El-Qist: Journal of Islamic Economics and Business (JIEB), 7(1), 1408-1430. Retrieved from http://jurnalfebi.uinsby.ac.id/index.php/elqist/article/view/102

Gozaly, A. Y. (2019). Penerapan Ta'zir dan Ta'widh pada lembaga keuangan syariah: Penelitian di Bank BRI Syariah KCP Majalaya dan Bank Syariah Mandiri Jatinangor. Retrieved from http://digilib.uinsgd.ac.id/25787/

Hariyanti, I. (2013). Restrukturisasi dan Penghapusan Kredit Macet. Jakarta: Elex Media Komputindo.

Heriadi, M. F. (2017). Implementasi Program CVC (Customs Visit Customer) Kantor Pengawasan dan Pelayanan Bea Cukai Tipe Madya Pabean B Dumai. Jurnal Online Mahasiswa (JOM) Bidang Ilmu Sosial Dan Ilmu Politik, 5(1), 1-12. Retrieved from https://jom.unri.ac.id/index.php/JOMFSIP/article/view/17480

Herijanto, H. Wawancara dengan Pakar Ta'widh. , (2020).

Hermawan. Wawancara dengan Nasabah KPR Platinum iB Bank BTN KCPS Karawaci. , (2020).

Kukuh, B. Wawancara dengan Financing Service Bank BTN KCPS Karawaci. , (2020).

Kuswati, S. M. (2015). Cara Gampang Membeli Rumah Tanpa Modal: Tips Mendapatkan Modal Awal, Teknik Mengatur pendapatan Modal, Trik Memilih Rumah Murah dan Nyaman. Jakarta: Lembar Langit Indonesia. 
Abdul Rachman, Fikriana Aini

Mashilal. (2020). Risk Of Sharia Banking In Indonesia: Viewed From Types Of Financing. ARBAH: Journal of Islamic Finance and Banking, 2(1), 61-80. https://doi.org/http://dx.doi.org/10.21580/alarbah.v2i1.5669

Nani, L. (2018). Analisis Pengelolaan Dana Ta'zir Bagi Nasabah Wanprestasi dalam Meningkatkan Kedisiplinan Nasabah (Studi Pada PT. Bank Syariah Mandiri Kantor Cabang Teluk Betung Bandar Lampung) (UIN Raden Intan Lampung). Retrieved from http://repository.radenintan.ac.id/4901/

Nihayah, A. Z., \& Rifqi, L. H. (2020). Variables Determining For Impairment On Productive Assets In Islamic Banks In Indonesia. Journal of Islamic Finance and Banking, 2(1), 1-16. https://doi.org/http://dx.doi.org/10.21580/al-arbah.v2i1.5539

Nurdin, I., \& Hartati, S. (2019). Metodologi Penelitian Sosial. Surabaya: Media Sahabat Cendekia.

Pangestu, M. T. (2019). Pokok-Pokok Hukum Kontrak. Makassar: CV. Social Politic Genius.

Sarjadinata, A. Wawancara dengan Branch Manager Bank BTN KCPS Karawaci. , (2020).

Sholihin. (2013). Buku Pintar Ekonomi Syariah. Jakarta: Gramedia Pustaka Utama.

Simanjutak. (2017). Hukum Perdata Indonesia. Jakarta: Kencana.

Suadi, A. (2018). Penyelesaian Sengketa Ekonomi Syariah: Penemuan dan Kaidah Hukum. Jakarta: Prenada Media.

Usman, R. (2010). Produk dan Akad Perbankan Syariah di Indonesia (Implementasi dan Aspek Hukum). Bandung: Citra Adhitya Bakti.

Yahman. (2016). Karakteristik Wanprestasi \& Tindak Pidana Penipuan. Jakarta: Kencana.

Yunus, M. (1989). Kamus Arab-Indonesia. Jakarta: Gema PT. Mahmud Yunus Madzuryah. 